Przegląd Narodowościowy / Review of Nationalities • nr 7/2017 • World of Slavs / Świat Słowian

\title{
At the heart of Orthodoxy. Around the issues of PACP in the Białystok region
}

\author{
W sercu prawosławia. \\ Wokół problematyki PAKP na Białostocczyźnie
}

The Polish Autocephalous Orthodox Church is one of the autocephalous (independent) Orthodox Churches. Its origins date back to the time of the Apostles and the first Christian communities ${ }^{1}$. Orthodoxy is one of the three branches of Christianity. It is characterized, among others by continuity of tradition, own liturgy and independence of local churches. Its homeland is the multinational and multicultural Roman Empire with Palestine as its province. The roots of Orthodoxy should be sought in the Holy Land, and in Byzantium it was given its own final form. The Orthodox Church developed on the basis of culture and Judeo-Christian, Hellenic, Syrian and Egyptian traditions. To this day it has retained certain dogmatic forms and liturgical principles, which already formed in the oldest period of Christian history. The term "Orthodoxy" itself derives from Byzantium and is an Old Slavonic trans-

\footnotetext{
1 E. Przybył, Prawosławie, Kraków 2006, p. 10, see more: J.A. McGuckin, The Orthodox Church. An Introduction to its History, Doctrine, and Spiritual Culture, Oxford 2008.
}

Polski Autokefaliczny Kościół Prawosławny jest jednym $\mathrm{z}$ autokefalicznych (samodzielnych) Kościołów prawosławnych. Jego początki sięgają czasów apostolskich i pierwszych gmin chrześcijańskich ${ }^{1}$. Prawosławie jest jedną z trzech gałęzi chrześcijaństwa. Charakteryzuje się m.in. ciągłością tradycji, własną liturgią i niezależnością lokalnych Kościołów. Jego ojczyzną jest wielonarodowe i wielokulturowe Cesarstwo Rzymskie z Palestyną jako jego prowincją. Korzeni prawosławia należy szukać w Ziemi Świętej, a w Bizancjum uzyskało ono jedynie swój ostateczny kształt. Kościół prawosławny rozwijał się, opierając się na kulturze i tradycji: judeochrześcijańskiej, helleńskiej, syryjskiej i egipskiej. Do dziś zachował pewne formy dogmatyczne, jak i zasady liturgiczne, które ukształtowały się już w najstarszym okresie dziejów chrześcijaństwa. Samo określenie „prawosławie” wywodzi się

${ }^{1}$ E. Przybył, Prawosławie, Kraków 2006, s. 10, szerzej zob. J.A. McGuckin, The Orthodox Church. An Introduction to its History, Doctrine and Spiritual Culture, Oxford 2008.

\footnotetext{
* Correspondence address: Instytut Politologii, Uniwersytet Zielonogórski, Al. Wojska Polskiego 69, 65-762 Zielona
} Góra, Polska, e-mail: stefan.dudra@wp.pl. 
lation of the Greek word ortodoxia - legitimacy $^{2}$.

In the Christianization of Central and Eastern Europe, the brothers Cyril and Methodius played a key role ${ }^{3}$. Their activities proved to be fundamental to the culture of the Slavs, beginning the development of the language and literature and the Slavic tradition of the Orthodox Church. They translated the Bible into Slavic and created the alphabet (Cyrillic) commonly adopted in the Orthodox Church. In the opinion of Aristides Papadakis in the Cyril and Methodius missions "are the roots of the Slavonic Church, the common liturgical language still used by Slavic Orthodox Christians"' . This work was continued by their disciples (among others Clement who settled in Bulgaria and later became the Archbishop of Ohrid). Cyril and Methodius are considered saint by both the Orthodox Church and the Roman Catholic Church (in 1980, Pope John Paul II announced them, together with St Benedict of Nursia, saint co-patrons of Europe). In the Orthodox Church, they are also called "equal to apostles" 5 . The Polish Autocephalous Orthodox Church in its ecclesial consciousness refers precisely

2 Fr. H. Paprocki, Prawosławie w Polsce, Olszanica 2008, p. 7; S. Wojtkowiak, Prawosławie wczoraj i dziś, Warszawa 1995, p. 3.

3 See: Apostołowie Słowian. Żywoty Konstantyna i Metodego, introduction T. Lehr-Spławiński, addenda L. Moszyński, Warszawa 1988; Pasterze wiernych Słowian: Święci Cyryl i Metody, ed. A. Naumow, Kraków 1995.

4 A. Papadakis, Zarys dziejów Kościoła prawosławnego, [in:] Prawosławie. Światło ze wschodu, ed. K. Leśniewski, Lublin 2009, p. 648.

5 A. Charkiewicz, Równi Apostołom Oświeciciele Słowian, "Wiadomości PAKP" 2013, No 6, p. 15. z Bizancjum i jest starosłowiańskim tłumaczeniem greckiego słowa ortodoxia prawowierność ${ }^{2}$.

W chrystianizacji Europy Środkowo-Wschodniej ważną rolę odegrali bracia Cyryl i Metody ${ }^{3}$. Ich działalność okazała się fundamentalna dla kultury Słowian, zapoczątkowując rozwój języka i piśmiennictwa oraz słowiańskiej tradycji Cerkwi prawosławnej. Przełożyli Biblię na język słowiański i stworzyli alfabet (cyrylicę) przyjęty powszechnie w Kościele prawosławnym. W opinii Aristeidesa Papadakisa w misjach Cyryla i Metodego „tkwią korzenie Kościoła słowiańskiego, wspólnego języka liturgicznego wciąż używanego przez słowiańskich chrześcijan prawosławnych"4. Dzieło to było kontynuowane przez ich uczniów (m.in. Klemensa, który osiadł w Bułgarii i został później arcybiskupem Ochrydy). Cyryl i Metody uważani są za świętych zarówno przez Cerkiew prawosławną, jak i Kościół rzymskokatolicki (w 1980 r. papież Jan Paweł II ogłosił ich, oprócz św. Benedykta z Nursji, współpatronami Europy). W prawosławiu tytułowani są również „równymi apostołom" . Polski Autokefaliczny Kościół Prawosławny w swojej świadomości eklezjalnej

2 Ks. H. Paprocki, Prawosławie w Polsce, Olszanica 2008, s. 7; S. Wojtkowiak, Prawosławie wczoraj i dziś, Warszawa 1995, s. 3.

3 Zob. Apostołowie Słowian. Żywoty Konstantyna i Metodego, wstęp T. Lehr-Spławiński, uzupełnienia L. Moszyński, Warszawa 1988; Pasterze wiernych Słowian: Święci Cyryl i Metody, oprac. A. Naumow, Kraków 1995.

4 A. Papadakis, Zarys dziejów Kościoła prawosławnego, [w:] Prawosławie. Światło ze wschodu, red. K. Leśniewski, Lublin 2009, s. 648.

5 A. Charkiewicz, Równi Apostołom Oświeciciele Słowian, „Wiadomości PAKP” 2013, nr 6, s. 15. 
to the Cyrilometodia tradition ${ }^{6}$. In this context, it is not a foreign element, or how unreasonably and uncritically it was (and is often) seen as the legacy of tsarist Russia. At the same time, the Orthodox religion, its culture, through centuries connected with the Polish statehood, was and is a part of Polish culture.

The history of the Orthodox Church in postwar Poland already possesses rich literature. It became the subject of research among others of Kazimierz Urban, Antoni Mironowicz, Grzegorz Kuprianowicz ${ }^{7}$. The study also included different regions of the Polish state (Fr Grzegorz Sosna, Doroteusz Fionik, Stefan Dudra, Piotr Gerent, Krzysztof Sychowicz) ${ }^{8}$. The book Cerkiew prawosławna na terenie województwa białostockiego w latach 1944-1956 (The Orthodox Church in Biatystok Voivodship in 1944-1956) by Fr. Arkadiusz Barańczuk refers to the latter context. The work consists

${ }^{6}$ About Ciril and Metthodius's mission see: A. Mironowicz, Kościół prawosławny w państwie Piastów i Jagiellonów, Białystok 2003, pp. 27-34; Metropolita Sawa (Hrycuniak), Ślady misyjnej działalności św. Metodego na ziemiach polskich, "Almanach Diecezjalny" 2005, vol. 1, Gorlice 2005, pp. 7-19.

7 K. Urban, Kościół prawosławny w Polsce 1945-1970, Kraków 1996; idem, Kościół prawosławny w Polsce 1944-1956. Studia i materiały, Kraków 1998; A. Mironowicz, Kościół prawosławny na ziemiach polskich w XIX i XX wieku, Białystok 2005; G. Kuprianowicz, Prawosławie w Polsce od 1918 roku do współczesności, [in:] Prawosławie. Światło wiary i zdrój życia, ed. K. Leśniewski, Lublin 2009.

${ }^{8}$ G. Sosna, D. Fonik, Dzieje Cerkwi w Bielsku Podlaskim, Białystok 1995; idem, Szczyty. Dzieje wsi i parafii, Bielsk Podlaski-Ryboły-Białystok 2005; S. Dudra, Kościół prawosławny na ziemiach zachodnich i pótnocnych Polski po II wojnie światowej, Zielona Góra 2004; idem, Kościół prawosławny na terenie Polski południowo-wschodniej, "Limes. Studia i materiały z dziejów Europy Środkowo-Wschodniej” 2010-2011, No 3-4, Rzeszów 2011, pp. 208-227; P. Gerent, Prawosławie na Dolnym Śląsku w latach 1945-1989, Toruń 2007. odwołuje się właśnie do tradycji cyrylometodiańskiej. W tym kontekście nie jest elementem obcym czy - jak bezpodstawnie i bezkrytycznie postrzegany był (i często jest) - spuścizną carskiej Rosji. Jednocześnie religia prawosławna, jej kultura, poprzez stulecia związana z państwowością polską, była i jest częścią kultury polskiej.

Dzieje Kościoła prawosławnego w powojennej Polsce mają już bogatą literaturę. Stał się on przedmiotem badań m.in. Kazimierza Urbana, Antoniego Mironowicza czy Grzegorza Kuprianowicza ${ }^{7}$. Badaniami objęto również różne regiony państwa polskiego (ks. Grzegorz Sosna, Doroteusz Fionik, Stefan Dudra, Piotr Gerent, Krzysztof Sychowicz) $)^{8}$. W ten ostatni kontekst wpisuje się książka ks. Arkadiusza Barańczuka Cerkiew prawosławna na terenie województwa białostockiego $w$ latach 1944-1956. Składa się z czterech rozdziałów zatytułowanych kolejno: Sytuacja

${ }^{6}$ O misji Cyryla i Metodego zob. A. Mironowicz, Kościół prawosławny w państwie Piastów i Jagiellonów, Białystok 2003, s. 27-34; Metropolita Sawa (Hrycuniak), Ślady misyjnej działalności św. Metodego na ziemiach polskich, „Almanach Diecezjalny” 2005, t. 1, Gorlice 2005, s. 7-19.

K. Urban, Kościół prawosławny w Polsce 1945-1970, Kraków 1996; idem, Kościół prawosławny w Polsce 1944-1956. Studia i materiały, Kraków 1998; A. Mironowicz, Kościół prawosławny na ziemiach polskich w XIX i XX wieku, Białystok 2005; G. Kuprianowicz, Prawosławie w Polsce od 1918 roku do współczesności, [w:] Prawosławie. Światło wiary i zdrój życia, red. K. Leśniewski, Lublin 2009.

${ }^{8}$ G. Sosna, D. Fonik, Dzieje Cerkwi w Bielsku Podlaskim, Białystok 1995; idem, Szczyty. Dzieje wsi i parafii, Bielsk Podlaski-Ryboły-Białystok 2005; S. Dudra, Kościół prawosławny na ziemiach zachodnich i pótnocnych Polski po II wojnie światowej, Zielona Góra 2004; idem, Kościół prawosławny na terenie Polski południowo-wschodniej, „Limes. Studia i materiały z dziejów Europy Środkowo-Wschodniej" 2010-2011, nr 3-4, Rzeszów 2011, s. 208-227; P. Gerent, Prawosławie na Dolnym Śląsku w latach 1945-1989, Toruń 2007. 
of four chapters entitled in turn: Sytuacja polityczna ziemi białostockiej w kontekście II wojny światowej (Political situation of the land of Biatystok in the context of World War II); "Schizma białostocka" wydarzenia $z$ lat 1944-1946 ("The Schism of Bialystok" - events from 1944-1946); Sytuacja i rola Cerkwi prawosławnej na Białostocczyźnie do roku 1948/1949 (The situation and role of the Orthodox Church in Bialystok until 1948/1949); Cerkiew prawosławna w nowych realiach społecznopolitycznych (przełom 1948/1949 oraz okres późniejszy) (Orthodox Church in the new socio-political realities [breakthrough 1948/1949 and later]). As the aim of his work Fr. Barańczuk settled the "presentation of the role and position of the Orthodox Church" in Białystok Province, which was "an arena for many complex social, military and political processes" (p. 7). The temporal scope of the development is a turbulent period in the post-war history of the Orthodox Church. Starting with the so-called "Schism of Białystok" (the definition of Kazimierz Urbana) or the more precise definition of "Bielsk schism" (Piotr Chomik) $)^{9}$, when the period of religious duality in the Church occurred (threatening its annihilation), the difficult second half of the 1940s (repression and surveillance of the clergy, unstable administrative

9 P. Chomik believes that the more appropriate name is "Bielsk schizm", since the main events connected with it took place in Bielsk Podlaski and in Bielsk county, see: Schizma bielska jako przykład problemów jurysdykcyjnych Kościoła prawosławnego na Białostocczyźnie w latach 1944-1946, [in:] P. Chomik, Cerkiew prawosławna $w$ Polsce i krajach sasiednich. Od przeszłości do współczesnych problemów bezpieczeństwa, Białystok 2015, p. 117. polityczna ziemi białostockiej w kontekście II wojny światowej; Cerkiew prawosławna w okresie II wojny światowej na terenie dawnych ziem II Rzeczypospolitej (lata 1939-1944); „Schizma białostocka” - wydarzenia $z$ lat 1944-1946; Sytuacja i rola Cerkwi prawosławnej na Białostocczyźnie do roku 1948/1949; Cerkiew prawosławna $w$ nowych realiach społeczno-politycznych (przełom 1948/1949 oraz okres późniejszy). Jako cel pracy ks. Barańczuk wyznaczył „przedstawienie roli i pozycji Cerkwi prawosławnej" na terenie województwa białostockiego, które było „areną wielu skomplikowanych procesów społecznych, militarnych i politycznych" (s. 7). Zakres temporalny opracowania stanowi burzliwy okres w powojennych dziejach Kościoła prawosławnego, poczynając od tzw. „schizmy białostockiej" (określenie Kazimierza Urbana) lub precyzyjniejszego określenia „schizmy bielskiej” (Piotr Chomik) ${ }^{9}$, kiedy to wystąpił okres dwuwładzy religijnej w Kościele (grożący nawet jego unicestwieniem), przez trudną drugą połowę lat 40 . $\mathrm{XX}$ w. (represje i inwigilacja duchowieństwa, nieustabilizowana struktura administracyjna) oraz wydarzenia z pierwszej połowy lat 50., które w polityce wyznaniowej miały ograniczyć stan jego posiadania oraz całkowicie podporządkować władzom państwowym.

${ }^{9}$ P. Chomik uważa, że bardziej adekwatna nazwa to „schizma bielska”, gdyż główne wydarzenia z nią związane odbywały się w Bielsku Podlaskim i na terenie powiatu bielskiego, zob. Schizma bielska jako przykład problemów jurysdykcyjnych Kościoła prawosławnego na Białostocczyźnie w latach 19441946, [w:] P. Chomik, Cerkiew prawosławna w Polsce $i$ krajach sasiednich. Od przeszłości do wspótczesnych problemów bezpieczeństwa, Białystok 2015, s. 117. 
structure) and the events of the first half of the fifties, which in the religious policy were to reduce the state of its possession and completely subordinate to the state authorities.

When analyzing the situation of PACP after the end of World War II, its development possibilities, it is necessary to remember the socio-political conditions in which it conducted its pastoral activity. The main determinant was the material condition resulting from the changes of the Polish state borders and the relocation of Belarusians, Ukrainians and Lemkos to the USSR and the BSSR in 1944-1946 (as a result of which it lost its basic social base $)^{10}$ and displacement within the "Vistula" operation (1947) which led to the weakening and partial decay (in the Podkarpacie region) of the activities of Orthodox parishes. At the same time, they forced the Church to build the administrative structure on the so-called Recovered Territories ${ }^{11}$. On the basis of preserved

10 According to general assessments in 19441946 from 450 to 520 thousand people (including about 170-180 thousand Orthodox people from the Chełm region and southern Podlasie and about 15 thousand from Lemkivshchyna were displaced. Over 36 thousand people of Belarusian nationality were displaced from Białystok region, see: E. Mironowicz, Białorusini w Polsce 1944-1949, Warszawa 1993, p. 111; E. Misiło, Repatriacja czy deportacja. Przesiedlenie Ukraińców z Polski do USRR 1944-1946, vol. 2, Dokumenty, Warszawa 1999, p. 357; J. Pisuliński, Przesiedlenie ludności ukraińskiej z Polski do USRR w latach 1944-1947, Rzeszów 2009, p. 508; S. Dudra, Kościół prawosławny wobec przesiedleń ludności łemkowskiej do Ukraińskiej Socjalistycznej Republiki Radzieckiej w latach 1944-1946, [in:] Łemkowie, Bojkowie, Rusini - historia, współczesność, kultura materialna i duchowa, Słupsk 2016, vol. 6, pp. 61-63.

11 See: P. Gerent, Wierni wyznania prawosławnego na Dolnym Śląsku $w$ świetle powojennych migracji ludności, "Zeszyty Naukowe Studenckiego
Dokonując analizy sytuacji PAKP po zakończeniu II wojny światowej, jego możliwości rozwojowych, należy pamiętać o uwarunkowaniach społeczno-politycznych, w których przyszło mu prowadzić działalność duszpasterską. Głównym determinantem był stan materialny będący wynikiem zmian granic państwa polskiego i przesiedleń ludności białoruskiej, ukraińskiej i łemkowskiej do USRR i BSRR w latach 1944-1946 (w ich wyniku utracił on podstawową bazę społeczną) $)^{10}$ oraz wysiedleń w ramach akcji „Wisła” (1947), które doprowadziły do osłabienia i częściowego zaniku (na Podkarpaciu) działalności parafii prawosławnych. Jednocześnie wymusiły na Cerkwi konieczność budowy od podstaw struktury administracyjnej na tzw. Ziemiach Odzyskanych ${ }^{11}$. Na podsta-

10 Według ogólnych szacunków w latach 1944-1946 wysiedlono z Polski do USRR od 450 do ok. 520 tys. osób (w liczbie tej znalazło się ok. 170-180 tys. prawosławnych z Chełmszczyzny i południowego Podlasia oraz ok. 15 tys. z Łemkowszczyzny). Z województwa białostockiego wysiedlono ponad 36 tys. osób narodowości białoruskiej, zob. E. Mironowicz, Białorusini w Polsce 1944-1949, Warszawa 1993, s. 111; E. Misiło, Repatriacja czy deportacja. Przesiedlenie Ukraińców z Polski do USRR 1944-1946, t. 2, Dokumenty, Warszawa 1999, s. 357; J. Pisuliński, Przesiedlenie ludności ukraińskiej z Polski do USRR w latach 1944-1947, Rzeszów 2009, s. 508; S. Dudra, Kościół prawosławny wobec przesiedleń ludności łemkowskiej do Ukraińskiej Socjalistycznej Republiki Radzieckiej w latach 19441946, [w:] Łemkowie, Bojkowie, Rusini - historia, współczesność, kultura materialna i duchowa, Słupsk 2016, t. 6, s. 61-63.

11 Zob. P. Gerent, Wierni wyznania prawosławnego na Dolnym Ślasku $w$ świetle powojennych migracji ludności, „Zeszyty Naukowe Studenckiego Koła Ukrainoznawczego", z. 3, Wrocław 1996; G. Kuprianowicz, Akcja „Wisła” a Kościół prawosławny, [w:] Akcja „Wisła”, red. J. Pisuliński, Warszawa 2003; S. Dudra, Kształtowanie się struktury administracyjnej prawosławnej diecezji wrocławsko-szczecińskiej po II wojnie światowej, „Studia Zachodnie” 2008, t. 10 , s. 103-126. 
sources, compared to the pre-war statistics, it can be stated that the number of parishes decreased from 1579 to 169 , churches from 1947 to 233 , clergy from 1725 to 190 , deacons from 206 to 25 , psalmists from 1593 to 169 and cemeteries from 1965 to $234^{12}$. By evaluating the activities of the PACP in post-war Poland and the decisions taken by its hierarchies and clergy, one must remember the material conditions of the Church. They influenced essentially the attitude towards the state authorities (both central and regional) and their policies (national and international).

Fr. Barańczuk presented the events in the Białystok region from 1944 to 1946 and the beginning of the jurisdiction dispute (the so-called "schism of Białystok") begins its analysis from mid-1944 (pp. 41-42). However, the origin of the split in the Orthodox Church in this area should be sought in the processes taking place in the Orthodox church after 1918. Their source was primarily unregulated relations with the Moscow Patriarchate resulting from receiving autocephaly in 1924 by the Orthodox Church in Poland from the $\mathrm{Pa}$ triarchate of Constantinople. The way of admission was questioned by some ecclesiastical circles (both the hierarchy and

Koła Ukrainoznawczego", z. 3, Wrocław 1996; G. Kuprianowicz, Akcja „Wisła” a Kościół prawosławny, [in:] Akcja "Wisła", ed. J. Pisuliński, Warszawa 2003; S. Dudra, Kształtowanie się struktury administracyjnej prawosławnej diecezji wrocławsko-szczecińskiej po II wojnie światowej, "Studia Zachodnie" 2008, vol. 10, pp. 103-126.

12 See: K. Urban, Kościół prawosławny w Polsce w latach 1944-1956..., p. 139; W. Bendza, Regulacja kościelnych spraw majątkowych na przykładzie Kościoła prawosławnego w Polsce, Warszawa 2009, p. 43. wie zachowanych źródeł, w porównaniu z przedwojennymi statystykami, można stwierdzić, że liczba parafii zmniejszyła się z 1579 do 169, świątyń z 1947 do 233, duchownych z 1725 do 190, diakonów z 206 do 25, psalmistów z 1593 do 169 oraz cmentarzy z 1965 do $234^{12}$. Oceniając działalność PAKP w powojennej Polsce oraz decyzje podejmowane przez jej hierarchów i duchowieństwo, należy pamiętać o uwarunkowaniach materialnych Kościoła. W sposób zasadniczy wpływały one na stosunek do władz państwowych (zarówno na poziomie centralnym, jak i regionalnym) oraz realizowanej przez nie polityki (krajowej i międzynarodowej).

Ksiądz Barańczuk, przedstawiając wydarzenia na Białostocczyźnie z lat 1944-1946 i początki sporu jurysdykcyjnego (tzw. schizma białostocka), rozpoczyna swoją analizę od połowy $1944 \mathrm{r}$. (s. 41-42). Jednak genezy rozłamu w Kościele prawosławnym na tym obszarze należy poszukiwać w procesach zachodzących w Cerkwi po 1918 r. Ich źródłem były przede wszystkim nieuregulowane stosunki z Patriarchatem Moskiewskim wynikłe z otrzymania w 1924 r. przez Cerkiew w Polsce autokefalii ze strony Patriarchatu Konstantynopolitańskiego. Sposób jej przyjęcia był kwestionowany przez część środowisk kościelnych (zarówno hierarchię, jak i duchowieństwo ${ }^{13}$.

12 Zob. K. Urban, Kościół prawosławny w Polsce w latach 1944-1956..., s. 139; W. Bendza, Regulacja kościelnych spraw majątkowych na przykładzie Kościoła prawosławnego w Polsce, Warszawa 2009, s. 43.

${ }^{13}$ M. Zyzykin, Autokefalia i zasady jej zastosowania, Warszawa 1931; A. Łotocki, Autokefalia. Zasady autokefalii, Warszawa 1932; M. Bendza, Droga Kościoła prawosławnego w Polsce do autokefalii, Białystok 2006; S. Dudra, Autokefalie Polskiego 
the clergy ${ }^{13}$. An additional element that reinforced the reluctance of the Polish state and part of the church hierarchy was the regulations of the authorities which were far subordinating and limiting ecclesial life (referring to the decree of the President of the Republic of 18 November 1938 on the relation of the State to the PACP and the decree of the Council of Ministers of 10 December 1938 Recognition of the "Inner Statute" of the Church) $)^{14}$. Some of the clergy also accused the metropolitan Dionizy (Waledyński) of too far reaching cooperation with the state authorities. The pre-war policy towards Orthodoxy and the Belarusian population towards its polonization was also important ${ }^{15}$.

The above-mentioned conditions resulted in the joining of the Orthodox parishes from the Białystok region to the Russian Orthodox Church by the Archbishop of Minsk Bazyli (Rotmirow) in December 1944. At the same time, most of the clergy rejected the jurisdiction of the Polish bishop Tymoteusz (Szretter). This led to many parochial conflicts (including

${ }^{13}$ M. Zyzykin, Autokefalia i zasady jej zastosowania, Warszawa 1931; A. Łotocki, Autokefalia. Zasady autokefalii, Warszawa 1932; M. Bendza, Droga Kościoła prawosławnego w Polsce do autokefalii, Białystok 2006; S. Dudra, Autokefalie Polskiego Autokefalicznego Kościoła Prawosławnego w polityce władz polskich i Patriarchatu Moskiewskiego, [in:] Polityka jako wyraz lub nastepstwo religijności, ed. R. Michalak, Sieniawa Żarska 2015, pp. 263-274.

${ }^{14}$ See: H. Świątkowski, Stan prawny Polskiego Autokefalicznego Kościoła Prawosławnego, Warszawa 1939; J. Osuchowski, Prawo wyznaniowe Rzeczypospolitej Polskiej 1918-1939, Warszawa 1967; M. Papierzyńska-Turek, Między tradycja a rzeczywistością. Państwo wobec prawosławia 1918-1939, Warszawa 1989.

${ }^{15}$ S. Dudra, Metropolita Dionizy (Waledyński) 1876-1960, Warszawa 2010, pp. 95-108.
Dodatkowym elementem wzmacniającym niechęć do państwa polskiego i częściowo hierarchii cerkiewnej były przepisy władz daleko uzależniające i ograniczające życie kościelne (chodziło o dekret Prezydenta Rzeczypospolitej z 18 listopada 1938 r. o stosunku Państwa do PAKP, jak również rozporządzenie Rady Ministrów z 10 grudnia 1938 r. o uznaniu „Statutu Wewnętrznego" Kościoła) ${ }^{14}$. Część duchowieństwa wysuwała też pod adresem metropolity Dionizego (Waledyński) oskarżenia o zbyt daleko idącą współpracę z władzami państwowymi. Nie bez znaczenia była też przedwojenna polityka wobec prawosławia i ludności białoruskiej zmierzająca do jej polonizacji ${ }^{15}$.

Wymienione uwarunkowania „zaowocowały" przyłączeniem przez arcybiskupa mińskiego Bazylego (Rotmirowa) w grudniu 1944 r. parafii prawosławnych z Białostocczyzny do Rosyjskiej Cerkwi Prawosławnej. Jednocześnie większość duchowieństwa odrzuciła jurysdykcję polskiego biskupa Tymoteusza (Szrettera). Doprowadziło to do wielu konfliktów parafialnych (m.in. w parafii w Orli, Narewce, Siemianówce), dezorganizowało życie religijne (odwoływanie duchownych z parafii, pozbawianie prawa odprawiania

Autokefalicznego Kościoła Prawosławnego w polityce władz polskich i Patriarchatu Moskiewskiego, [w:] Polityka jako wyraz lub nastepstwo religijności, red. R. Michalak, Sieniawa Żarska 2015, s. 263-274.

${ }_{14}$ Zob. H. Świątkowski, Stan prawny Polskiego Autokefalicznego Kościoła Prawosławnego, Warszawa 1939; J. Osuchowski, Prawo wyznaniowe Rzeczypospolitej Polskiej 1918-1939, Warszawa 1967; M. Papierzyńska-Turek, Między tradycja a rzeczywistościa. Państwo wobec prawosławia 1918-1939, Warszawa 1989.

${ }^{15}$ S. Dudra, Metropolita Dionizy (Waledyński) 1876-1960, Warszawa 2010, s. 95-108. 
parishes in Orla, Narewka, Siemianówka), disorganized religious life (dismissing clergy from parishes, depriving the right to worship). There was a temporary closure of churches (Szczyty), the administrative attribution of the parish to the jurisdiction of Archbishop Bazyli (among others in Choroszcza $)^{16}$. First and foremost, the whole situation violated the autocephalic principle of PACP. It was precisely for the autocephaly of 1924 that the Polish authorities, which unequivocally supported bishop Tymoteusz in this issue, invoked. The hierarch also received the support of Metropolitan Dionizy (Waledyński), who strongly advocated parochial affiliation in the Białystok region to Poland. He pointed out that the post-war changes of the border and the ongoing deportation to Ukraine, deprive the Orthodox Church of a considerable number of the faithful. In addition, the possible loss of the Białystok region could be the beginning of the end of the Orthodox Church in Poland. The situation that had arisen in the Białystok region was unfavorable for the Polish authorities, as it further undermined the sovereignty of the state, and also threatened to lose the independence of Orthodoxy in Poland. The jurisdictional issue was particularly important because it decided on the nature of relations with the Russian Orthodox Church. The decisions of the Minsk metropolitan Bazyli were contradictory both

16 See more: Białorusini $i$ stosunki polsko-białoruskie na Białostocczyźnie 1944-1956, vol. 1: August 1944-December, part 1: Sierpień 1944-grudzień 1945, ed. S. Iwaniuk, Białystok 1996; K. Sychowicz, Władze komunistyczne wobec Kościołów i związków wyznaniowych $w$ województwie białostockim w latach 1944-1975, Białystok 2013. nabożeństw). Dochodziło do czasowego zamykania świątyń (Szczyty), administracyjnego przypisywania parafii pod jurysdykcję abpa Bazylego (m.in. w Choroszczy ${ }^{16}$. Przede wszystkim cała sytuacja naruszała zasadę autokefaliczności PAKP. Właśnie na autokefalię z $1924 \mathrm{r}$. będą powoływać się polskie władze, które jednoznacznie wsparły w tej kwestii bpa Tymoteusza. Hierarcha uzyskał również poparcie metropolity Dionizego (Waledyński), który zdecydowanie opowiadał się za przynależnością parafii na Białostocczyźnie do Polski. Zwracał on uwagę, że zachodzące po wojnie zmiany graniczne i trwająca akcja przesiedleńcza na Ukrainę pozbawiają Cerkiew znaczącej liczby wiernych. Dodatkowo ewentualna utrata Białostocczyzny mogłaby stać się początkiem końca Kościoła prawosławnego w Polsce. Sytuacja, jaka wytworzyła się na Białostocczyźnie, była niekorzystna dla władz polskich, gdyż dodatkowo podważała suwerenność państwa, stanowiła też groźbę utraty niezależności prawosławia w Polsce. Problem jurysdykcyjny był szczególnie ważny, ponieważ decydował o charakterze relacji z Rosyjskim Kościołem Prawosławnym. Decyzje metropolity mińskiego Bazylego były sprzeczne zarówno z aktem autokefalii z 1924 r., przepisami dekretu prezydenta z 1938 r., jak i decyzjami przewodniczącego $\mathrm{PKWN}^{17}$. Osta-

${ }_{16}$ Zob. szerzej: Białorusini i stosunki polsko-białoruskie na Białostocczyźnie 1944-1956, t. 1: sierpień 1944- grudzień 1956, cz. 1: Sierpień 1944-grudzień 1945, oprac. S. Iwaniuk, Białystok 1996; K. Sychowicz, Władze komunistyczne wobec Kościołów $i$ związków wyznaniowych $w$ województwie białostockim w latach 1944-1975, Białystok 2013.

17 A. Mironowicz, Kościół prawosławny na ziemiach polskich w XIX i XX wieku..., s. 237. 
with the act of autocephaly of 1924, the provisions of the presidential decree of 1938, and the decisions of the chairman of the Polish Committee of National Liberation $(\mathrm{PKWN})^{17}$. Finally, under the influence of state authorities and their support for Bishop Tymoteusz, the conflict was resolved (in February 1946, the clergy supporting Archbishop Bazyli recognized the authority of Bishop Tymoteusz and metropolitan Dionizy). Fr. Barańczuk rightly points out the involvement of Polish and Soviet security services in the final solution of the conflict, among other things abductions and arrest of some of the clergy supporting Archbishop Bazyli (pp. 54-55). Questions about the actual inspirers of action that led to the so-called "Schism of Białystok" and what chances of success, taking into account the political realities, the initiative had, are really important. The author (referring, inter alia, to studies by Eugeniusz Mironowicz and Piotr Kołakowski) $)^{18}$ points to the Soviet "decision circles" (p. 60). The open question remains whether the prospects of including these areas in the USSR were sought or whether they were intended only through subordinated parish structures to influence the local Orthodox population in decision to resettle to the BSRR (p. 61). It should not be excluded that immediately after the war the Moscow Patriarchate tried to take over the Orthodox Church in Poland under its own jurisdiction (events in Białystok could only be an attempt at probing such

17 A. Mironowicz, Kościół prawosławny na ziemiach polskich $w$ XIX $i$ XX wieku..., p. 237.

18 E. Mironowicz, Białorusini w Polsce..., s. 138; P. Kołakowski, NKWD $i$ GRU na ziemiach polskich 1939-1945, Warszawa 2002, p. 248. tecznie pod wpływem władz państwowych i ich wsparcia dla bpa Tymoteusza konflikt został rozwiązany (w lutym 1946 r. duchowieństwo popierające abpa Bazylego uznało zwierzchnictwo bpa Tymoteusza i metropolity Dionizego). Ksiądz Barańczuk słusznie zauważa zaangażowanie polskich i radzieckich służb bezpieczeństwa w końcowe rozwiązanie konfliktu, m.in. porwania i aresztowania części duchowieństwa popierającego abpa Bazylego (s. 54-55). Trafne są również pytania dotyczące rzeczywistych inspiratorów działań, które doprowadziły do tzw. schizmy białostockiej oraz tego, jakie szanse powodzenia, uwzględniając ówczesne realia polityczne, miała podjęta inicjatywa. Autor (powołując się m.in. na badania Eugeniusza Mironowicza oraz Piotra Kołakowskiego ${ }^{18}$ ) wskazuje na radzieckie „kręgi decyzyjne” (s. 60). Pytaniem otwartym pozostaje, czy dążono do ewentualnego włączenia tych terenów do ZSRR, czy zamierzano tylko poprzez podporządkowane struktury parafialne wpływać na miejscową ludność prawosławną w podejmowaniu decyzji o przesiedleniach do BSRR (s. 61). Nie należy wykluczyć, że bezpośrednio po wojnie Patriarchat Moskiewski próbował przejąć prawosławnych w Polsce pod własną jurysdykcję (wydarzenia na Białostocczyźnie mogły być tylko próbą sondowania tego typu możliwości ${ }^{19}$. Jednocześnie są to zagadnienia wymagające dalszych badań naukowych, głównie z uwzględnieniem materiałów znajdujących się w archiwach

18 E. Mironowicz, Białorusini w Polsce..., s. 138; P. Kołakowski, NKWD $i$ GRU na ziemiach polskich 1939-1945, Warszawa 2002, s. 248.

${ }^{19}$ K. Sychowicz, op. cit., s. 70. 
possibilities ${ }^{19}$. At the same time, these are the issues that require further scientific research, mainly taking into account the materials found in state archives of the Russian Federation and Belarus and in the archives of the Church of the Moscow Patriarchate.

In July 1946, the Diocese of Białystok-Bielsk (bishop Tymoteusz was appointed the Ordinary) was erected to strengthen the position of the hierarchy and contribute to the stabilization of religious life in this area. The attempt to set up a new church organization in December 1944 was unsuccessful. The PACP allies were state authorities, who also became the main arbitrator in resolving conflicts in the church. This will also be visible later in both the Church and the Białystok region, which after the war became the "center" of Orthodoxy in Poland. The newly erected diocese at that time had 69 parishes serviced by 51 parish priests, 4 vicars and 2 deacons. At the same time, it was the largest administrative unit of the Orthodox Church in Poland. The relatively stable situation connected with the parish network (minor changes related to the erection of new establishments) was characteristic only for this region. The other changes were dynamic, parish were being both erected and closed (pp. 64-65).

An analysis of the situation of the Orthodox Church in Białystok until 1949, taking into account the state-PACP relationship and the shaping administrative structure (decanal and parish network), was shown in correlation with the political

${ }^{19}$ K. Sychowicz, op. cit., p. 70. państwowych Federacji Rosyjskiej i Białorusi oraz $\mathrm{w}$ archiwach kościelnych Patriarchatu Moskiewskiego.

Erygowanie w lipcu 1946 r. diecezji białostocko-bielskiej (ordynariuszem został mianowany bp Tymoteusz) miało umocnić pozycję hierarchy oraz przyczynić się do stabilizacji życia religijnego na tym obszarze. Podejmowane od grudnia 1944 r. próby utworzenia nowej organizacji kościelnej zakończyły się niepowodzeniem. Sojusznikiem PAKP były władze państwowe, które stawały się też głównym arbitrem w rozstrzyganiu sytuacji konfliktowych w Cerkwi. Będzie to widoczne także w okresie późniejszym zarówno w odniesieniu do całego Kościoła, jak i do obszaru Białostocczyzny, która po wojnie stała się ,centrum” prawosławia w Polsce. Nowo erygowana diecezja liczyła w tym czasie 69 parafii obsługiwanych przez 51 proboszczów, 4 wikariuszy i 2 diakonów. Tym samym była najliczniejszą jednostką administracyjną Cerkwi prawosławnej w Polsce. W miarę stabilna sytuacja związana $\mathrm{z}$ siecią parafialną (niewielkie zmiany związane $\mathrm{z}$ erygowaniem nowych placówek) była charakterystyczna wyłącznie dla tego regionu. W pozostałych zmiany były dynamiczne, następowało zarówno erygowanie, jak i zamykanie parafii (s. 64-65).

Analiza sytuacji Cerkwi prawosławnej na Białostocczyźnie do 1949 r. z uwzględnieniem relacji państwo-PAKP oraz kształtującej się struktury administracyjnej (sieć dekanalna i parafialna) ukazana została w korelacji do zachodzących przemian politycznych w Polsce (kształtujący się system stalinowski) oraz w samym Kościele (nadzór i ścisła kontrola nad duchowień- 
changes in Poland (the Stalinist system) and in the Church itself (supervision and strict control of the clergy, removal of the Metropolitan Dionizy from managing the Church in1948). In the latter case, the cooperation of the Soviet authorities with the Moscow Patriarchate was correlated with the subordination of the local Churches. One of its elements was their hierarchy personnel policy. This process was initially launched in Estonia, where in March 1945, after the Red Army occupied the territory, the Estonian Apostolic Orthodox Church was liquidated and parishes and the faithful were included in the structure of the Moscow Patriarchate ${ }^{20}$. The Orthodox Church in Czechoslovakia faced a similar fate. It was subordinated by the government decree to the Moscow Patriarchate in the second half of 1945, which created an exarchate headed by Archbishop Eleutherius (Vorontsov). The process of subjugating Orthodoxy took place in Hungary as well. Parishes operating under the Serbian Orthodox Church and the Patriarchate of Constantinople, turned to the patriarch of Moscow Alexey II for admission into the jurisdiction of the Russian Orthodox Church. Initially, the Temporary Board of Hungarian Orthodox Parishes was estab-

20 The Estonian Apostolic Orthodox Church in 1923 obtained autonomy within the jurisdiction of the Patriarchate of Constantinople. As in the latter case of the PACP, this act was not approved by the Moscow Patriarchate, A. Sychov, The Liquidation and the Attempts of Reopening of the Congregations of the Estonian Eparchy during the Governance of Nikita Hruschtschov in 1954-1964, http://www.orthodoxa. org/GB/estonia/documentsEOC/closingGB.htm [access on: 10.09.2014]. stwem, odsunięcie od zarządzania Cerkwią metropolity Dionizego w 1948 r.). W tym ostatnim przypadku nastąpiła korelacja współpracy władz radzieckich z Patriarchatem Moskiewskim w podporządkowywaniu sobie lokalnych Kościołów. Jednym z jej elementów była polityka kadrowa dotycząca hierarchii. Proces ten został m.in. zainicjowany w Estonii, w której po zajęciu przez Armię Czerwoną w marcu 1945 r. Estoński Apostolski Kościół Prawosławny został zlikwidowany, a parafie i wiernych włączono w struktury Patriarchatu Moskiewskiego ${ }^{20}$. Podobny los spotkał Cerkiew w Czechosłowacji, podporządkowaną w drugiej połowie $1945 \mathrm{r}$. dekretem rządowym Patriarchatowi Moskiewskiemu, który utworzył w Pradze egzarchat na czele $\mathrm{z}$ abpem Eleuteriuszem (Woroncow). Proces podporządkowywania prawosławia nie ominął też Węgier. Parafie działające w ramach Serbskiego Kościoła Prawosławnego i Patriarchatu Konstantynopolitańskiego zwróciły się do patriarchy moskiewskiego Aleksego II o przyjęcie w jurysdykcję Rosyjskiego Kościoła Prawosławnego. Początkowo powołany został Tymczasowy Zarząd Węgierskich Parafii Prawosławnych, a następnie w listopadzie 1949 r. erygowano dekanat węgierski ${ }^{21}$. Po-

${ }^{20}$ Estoński Apostolski Kościół Prawosławny w 1923 r. uzyskał autonomię w ramach jurysdykcji Patriarchatu Konstantynopolitańskiego. Podobnie jak w późniejszym przypadku PAK Pakt ten nie uzyskał akceptacji Patriarchatu Moskiewskiego, A. Sychov, The Liquidation and the Attempts of Reopening of the Congregations of the Estonian Eparchy during the Governance of Nikita Hruschtschov in 1954-1964, http://www.orthodoxa.org/GB/estonia/documentsEOC/closingGB.htm [dostęp: 10.09.2014]

${ }^{21}$ L. Péter, Church-State Relations and Civil Society in Hungary. A Historical Perspective, „Hungarian Studies" 1995, Vol. 10, No. 1, s. 19-20. 
lished and then the Hungarian deanery was erected in November $1949^{21}$. Human resources policy, in line with the vision promoted by the Moscow Patriarchate and local communist authorities, was also implemented in the Romanian and Bulgarian Churches. In 1948, after the death of patriarch Nikodem (Munteanu), a strong opponent of the communist authorities in Romania, as a result of government pressure on hierarchies Justinian (Marina) was chosen the new Patriarch. In the same year Stefan (Shokov) was forced to resign from the office of Bulgarian exarch Stefan. The Hierarch, with great authority and support of the faithful, was accused of sympathizing with the United Kingdom and the United States ${ }^{22}$. A similar scenario was realized in Poland. The activities of the hierarchy during the war were considered contradictory to the Polish rationale of the state (he was accused of excessive submission to the German occupying authorities, accused of being in touch with governor Hans Frank and the head of the Warsaw district Ludwig Fischer, and also the decision to issue an appeal for forced labor trips to Germany ${ }^{23}$. The issue of anti-

${ }^{21}$ L. Péter, Church-State Relations and Civil Society in Hungary. A Historical Perspective, "Hungarian Studies" 1995, Vol. 10, No 1, pp. 19-20.

${ }^{22}$ See more: D. Kalkandjieva, Balgarskata pravoslavna tsarkva i darzhavata 1944-1953, [in:] The Bulgarian Orthodox Church and the State, Sofia 1997; P. Caravia, V. Constantinescu, F. Stanescu, The Imprisoned Church: Romania 1944-1989, Bucharest 1999; C. Paiusan, R. Ciuceanu, The Romanian Orthodox Church under the Communist Regime, Vol. 1: 1945-1958, Bucharest 2001.

23 The allegiations of cooperating with the Nazi occupant were also directed to other ecclesiastical authorities, see: R. Michalak, Kościoły protestanckie $i$ władze partyjno-państwowe w Polsce (1945-1956), Warszawa 2002, pp. 66-71. litykę kadrową, zgodną z wizją lansowaną przez Patriarchat Moskiewski oraz lokalne władze komunistyczne, realizowano też w Kościołach rumuńskim i bułgarskim. W 1948 r. po śmierci patriarchy Nikodema (Munteanu), zdecydowanego przeciwnika władz komunistycznych w Rumunii, w wyniku rządowych nacisków na hierarchów nowym patriarchą został Justynian (Marina). W tym samym roku zmuszony został też do rezygnacji z urzędu bułgarski egzarcha Stefan (Szokow). Hierarcha cieszący się dużym autorytetem i poparciem wiernych został oskarżony o sympatyzowanie z Wielką Brytanią i USA ${ }^{22}$. Podobny scenariusz został zrealizowany w Polsce. Działalność hierarchy w czasie wojny uznano za sprzeczną z polską racją stanu (zarzucano mu zbytnią uległość wobec niemieckich władz okupacyjnych, oskarżano o kontakty z gubernatorem Hansem Frankiem i szefem dystryktu warszawskiego Ludwigiem Fischerem, zastrzeżenia budziły także decyzje dotyczące wydania apelu o wyjazdy na roboty przymusowe do Niemiec) ${ }^{23}$. W stosunku do metropolity Dionizego podnoszono również kwestię antysowieckich deklaracji i występowania przeciwko działaniom Patriarchatu Moskiewskiego w czasie II wojny światowej. Pojawiły

22 Szerzej zob. D. Kalkandjieva, Balgarskata pravoslavna tsarkva i darzhavata 1944-1953, [w:] The Bulgarian Orthodox Church and the State, Sofia 1997; P. Caravia, V. Constantinescu, F. Stanescu, The Imprisoned Church: Romania 1944-1989, Bucharest 1999; C. Paiusan, R. Ciuceanu, The Romanian Orthodox Church under the Communist Regime, Vol. 1: 1945-1958, Bucharest 2001.

${ }^{23}$ Zarzuty o współpracę z okupantem hitlerowskim kierowane były również do innych zwierzchności kościelnych, zob. R. Michalak, Kościoły protestanckie $i$ władze partyjno-państwowe $w$ Polsce (1945-1956), Warszawa 2002, s. 66-71. 
Soviet declarations and actions against the actions of the Moscow Patriarchate during the Second World War was also raised against Metropolitan Dionizy. There were also allegations of agency cooperation with the US and British embassies, or even as absurd as conducting intelligence activities in the areas joined to the west and north of Poland by the Orthodox Metropolitan Committee for the Removal Assistance for the Recovered Territories. This was a pattern worked out in the religious administration of communist countries. Some of the allegations (including contacts with German occupying authorities) were also applied in the later period not only to the Orthodox clergy.

In the post-war period, the Orthodox clergy found themselves under special "custody" of both the religious apparatus (the Department of Religious Affairs of the Ministry of Public Administration and the Office for Religious Affairs since 1950) as well as security. As early as January 1946, the local apparatus began to work out Fr. Anatol Kiryk (newly appointed Dean of the Białystok Province) and an object case code-named "Mikołaj" (the clergy of the Białystok parish of St. Nicholas) was opened. It was under pressure from both the state and the underground. The Orthodox Belarussians also became victims. The pacifications of the turn of January and February 1946, among others of villages Zaleszany, Wólka Wygonowska, Końcowizna, Zanie, Szpaki and Malesze became an important factor when deciding on trips to the BSSR and at the same time they affected the weakening of the PACP's potential in this area (e.g. from the się też zarzuty o współpracę agenturalną z ambasadą amerykańską i brytyjską czy nawet tak absurdalne jak prowadzenie przez Prawosławny Metropolitarny Komitet Niesienia Pomocy Przesiedleńcom na Ziemiach Odzyskanych działalności wywiadowczej na obszarach przyłączonych na zachodzie i północy Polski. Był to schemat wypracowany w administracji wyznaniowej państw komunistycznych. Część zarzutów (m.in. kontakty z okupacyjnymi władzami niemieckimi) stosowano też w późniejszym okresie wobec duchowieństwa nie tylko prawosławnego.

W powojennym okresie duchowieństwo prawosławne znalazło się pod szczególną „opieką” zarówno aparatu wyznaniowego (Departamentu Wyznaniowego Ministerstwa Administracji Publicznej, a od 1950 r. Urzędu do Spraw Wyznań), jak i bezpieczeństwa. Już w styczniu 1946 r. lokalny aparat rozpoczął rozpracowywanie ks. Anatola Kiryka (nowo mianowanego dziekana woj. białostockiego) oraz wszczęto sprawę obiektową o kryptonimie „Mikołaj” (objęto nią duchowieństwo białostockiej parafii św. Mikołaja). Poddane ono zostało presji zarówno ze strony władz państwowych, jak i zbrojnego podziemia. Ofiarami stali się też prawosławni Białorusini. Pacyfikacje z przełomu stycznia i lutego 1946 r. m.in. wsi: Zaleszany, Wólka Wygonowska, Końcowizna, Zanie czy Szpaki i Malesze stały się ważnym czynnikiem przy podejmowaniu decyzji o wyjazdach do BSRR i jednocześnie wpływały na osłabienie potencjału PAKP na tym terenie (np. ze wsi Malesze wyjechało ponad 30 prawosławnych rodzin, co stanowiło blisko połowę wszystkich mieszkańców 
Malesze village more than 30 Orthodox families left; almost half of all Orthodox people $)^{24}$. Adding to this abduction, systematic robbery of food, property, overlapping of contributions, or various types of punishment (e.g. public flogging), we get a picture of Belarusian life during this period. Fr. Barańczuk emphasizes that the most tragic example of armed underground activity was the "pacification rally" of the NZW unit (Narodowe Zjednoczenie Wojskowe - National Military Union) commanded by Capt. Romuald Rajs pseud. "Bury", which resulted in burning the aforementioned Belarusian villages and committing homicide on the peasants near the village of Puchły Stare. The main motive of the activities was the national and denominational determinant (p. 79).

Since 1950 the aforementioned Office for Religious Affairs dealt with religious matters. The PACP was supervised by the Department of Non-Catholic Denominations ${ }^{25}$. The scope of activities of the Department was very wide: from overseeing the proper implementation of the rules relating to religious unions, to overseeing

24 J. Kułak, Pacyfikacja wsi białoruskich w styczniu 1946 roku, "Biuletyn Instytutu Pamięci Narodowej” 2001, No 8; E. Mironowicz, Antykomunistyczne podziemie na Białorusi i na Białostocczyźnie w latach 1944-1948. Pamięć, mitologia, historia, "Białoruskie Zeszyty Historyczne” 2010, No 34, pp. 110-120.

${ }_{25}$ In addition, the UdSW (The Office for Religious Affairs) structure consisted of the General Department, the Roman Catholic Church Department, the Independent Section of the Supervision of Religious Associations, the Independent Section of the Supervision of the Church Fund, see: M. Krawczyk, Organy państwowo-partyjne odpowiedzialne za wytyczanie i realizowanie polityki wyznaniowej PRL, "Zeszyty Naukowe Uniwersytetu Przyrodniczo-Humanistycznego w Siedlcach". Seria Administracja i Zarządzanie 2011, No 89, p. 212. wyznania prawosławnego $)^{24}$. Dodając do tego uprowadzenia, systematyczne rabunki żywności, mienia, nakładanie kontrybucji czy różnego rodzaju kary (m.in. publiczne chłosty), otrzymamy obraz życia Białorusinów w tym okresie. Ksiądz Barańczuk podkreśla, że najbardziej tragicznym przykładem działań zbrojnego podziemia był „rajd pacyfikacyjny” oddziału NZW dowodzonego przez kpt. Romualda Rajsa ps. „Bury”, w wyniku którego doszło m.in. do spalenia wspomnianych powyżej wsi białoruskich oraz dokonanie mordu na chłopach koło wsi Puchły Stare. Głównym motorem działań był wyznacznik wyznaniowo-narodowościowy (s. 79).

Od 1950 r. sprawami wyznaniowymi zajmował się wspomniany już Urząd do Spraw Wyznań. Nadzór nad PAKP został umiejscowiony w Wydziale Wyznań Nierzymskokatolickich ${ }^{25}$. Zakres działań Wydziału był bardzo szeroki: od prowadzenia nadzoru nad prawidłowym wykonywaniem przepisów odnoszących się do związków religijnych, po nadzór nad szkolnictwem wyznaniowym oraz sprawami wniosków o rozdział subsydiów i dotacji rządowych na zaspokajanie potrzeb dane-

24 J. Kułak, Pacyfikacja wsi białoruskich w styczniu 1946 roku, „Biuletyn Instytutu Pamięci Narodowej" 2001, nr 8; E. Mironowicz, Antykomunistyczne podziemie na Białorusi i na Białostocczyźnie w latach 1944-1948. Pamięć, mitologia, historia, „Białoruskie Zeszyty Historyczne" 2010, nr 34, s. 110-120.

25 Ponadto strukturę UdSW tworzyły: Wydział Ogólny, Wydział Wyznania Rzymskokatolickiego, Samodzielny Referat Nadzoru Stowarzyszeń Wyznaniowych, Samodzielny Referat Nadzoru Funduszu Kościelnego, zob. M. Krawczyk, Organy państwowo-partyjne odpowiedzialne za wytyczanie i realizowanie polityki wyznaniowej PRL, „Zeszyty Naukowe Uniwersytetu Przyrodniczo-Humanistycznego w Siedlcach" 2011, Seria Administracja i Zarządzanie, nr 89, s. 212. 
religious education, and the applications for subsidiarity and government grants to meet the needs of a particular denomination $^{26}$. Close supervision was also exercised by the security organs. Actions against churches and religious unions was conducted since July 1944 under Section III of the Department I of the Public Security Administration. After the founding of the Ministry of Public Safety (1 January 1945), the current Department I took the name of Department I of the Division III of this department was responsible for fighting hostile agents among the clergy. It had its counterparts in voivodships (Section III of the Departments I) ${ }^{27}$ and counties (Section III of the Departments I). After 1956, the supervision was carried out within the Ministry of Interior (the Security Service ivision was established, and the church affairs were supervised by the Section $V$ of the Department III SB, which had its own sections in the voivodship headquarters of $\mathrm{MO}$ and the county MO departments). In this form, it survived practically until the end of the People's Republic of Poland ${ }^{28}$. Security service conducted, among others, cases of Fr. Anatol Mackiewicz and Fr. Eugeniusz Wichrow. The first, together with his wife and daughter, was arrested

26 Tymczasowy Statut Urzędu do Spraw Wyznań, M.P. 1950, No 58, poz. 905.

27 See: K. Szwagrzyk, Aparat bezpieczeństwa $w$ latach 1944-1956, [in:] Aparat bezpieczeństwa w Polsce. Kadra kierownicza, vol. 1: 1944-1956, ed. K. Szwagrzyk, Warszawa 2005, pp. 19-20.

28 See: H. Dominiczak, Organy bezpieczeństwa PRL $w$ walce z Kościołem katolickim 1944-1990. W świetle dokumentów MSW, Warszawa 2000. go wyznania ${ }^{26}$. Ścisły nadzór sprawowany był też przez organy bezpieczeństwa. Działania przeciwko kościołom i związkom wyznaniowym prowadzono już od lipca 1944 r. w ramach Sekcji III Wydziału I Resortu Bezpieczeństwa Publicznego. Po powstaniu Ministerstwa Bezpieczeństwa Publicznego (1 stycznia 1945) dotychczasowy Wydział I przyjął nazwę Departament I. Wydział III tego departamentu zajmował się m.in. zwalczaniem wrogiej agentury wśród duchowieństwa. Posiadał on swoje odpowiedniki w województwach (sekcje III wydziałów I) i powiatach (sekcje III referatów I) ${ }^{27}$. Nadzór ten po 1956 r. prowadzony był w ramach Ministerstwa Spraw Wewnętrznych (utworzono pion Służby Bezpieczeństwa, a sprawy kościelne znalazły się pod nadzorem Wydziału V Departamentu III SB, który miał swoje wydziały w komendach wojewódzkich MO i referaty w komendach powiatowych). W takiej formie przetrwał on praktycznie do końca $\mathrm{PRL}^{28}$. Aparat bezpieczeństwa prowadził m.in. sprawy ks. Anatola Mackiewicza i ks. Eugeniusza Wichrowa. Ten pierwszy, wraz $\mathrm{z}$ żoną i córką, został aresztowany w styczniu 1949 r. (oskarżony m.in. o współpracę z Niemcami, a nawet przyjęcie obywatelstwa radzieckiego w latach 1939-1941), a następnie w kwietniu wydalony z Polski. Do kraju powrócił dopiero latem $1955 \mathrm{r}$. Ksiądz Barańczuk podkreśla, że prawdziwe

26 Tymczasowy Statut Urzędu do Spraw Wyznań, M.P. z 1950, nr 58, poz. 905.

27 Zob. K. Szwagrzyk, Aparat bezpieczeństwa w latach 1944-1956, [w:] Aparat bezpieczeństwa w Polsce. Kadra kierownicza, t. 1: 1944-1956, red. K. Szwagrzyk, Warszawa 2005, s. 19-20.

28 Zob. H. Dominiczak, Organy bezpieczeństwa PRL $w$ walce $z$ Kościołem katolickim 1944-1990. W świetle dokumentów MSW, Warszawa 2000. 
in January 1949 (accused of cooperating with Germans, and even of accepting Soviet citizenship in 1939-1941), and then expelled from Poland in April. He returned to the country only in the summer of 1955. Fr. Barańczuk emphasizes that the real reasons for the expulsion of Fr. Mackiewicz may have been associated with his support of the Metropolitan Dionizy as the head of the PACP (p. 112). Tragically, the arrest of Fr. Wichrow (9 September 1948), who spent more than a year in custody without trial and died in February 1950.

A supplement to the publication of Fr. Barańczuk are issues concerning Orthodox Orthodox churches in the Białystok voivodship and the economic and material issues of the clergy. They influenced and shaped the developmental potential of PACP. An important "educational" role for clergy and hierarchs was the elaborate way of dealing with various requests and needs: from the opening of a pastoral institution to the positive (or not) opinion on the allocation of regulated materials for repairs or sanctification (p. 137). In such political and social conditions, the Orthodox Church came into being in the first postwar period of the People's Republic of Poland. powody wydalenia ks. Mackiewicza mogły być związane z jego poparciem udzielonym metropolicie Dionizemu jako zwierzchnikowi PAKP (s. 112). Tragicznie natomiast zakończyło się aresztowanie ks. Wichrowa (9 września 1948 r.), który przebywając ponad rok w areszcie bez procesu sądowego, zmarł w lutym $1950 \mathrm{r}$.

Elementem uzupełniającym publikację ks. Barańczuka są zagadnienia dotyczące wiernych Cerkwi prawosławnej w województwie białostockim oraz kwestie majątkowo-gospodarcze i materialne duchowieństwa. Wpływały one i kształtowały możliwości rozwojowe PAKP. Istotną rolę „wychowawczą" w stosunku do duchownych, jak również hierarchów, odgrywał rozbudowany tryb załatwiania różnych wniosków i potrzeb: począwszy od otwarcia placówki duszpasterskiej, a skończywszy na pozytywnej (lub nie) opinii co do przydziału reglamentowanych materiałów na remonty lub poświęcenie świątyń (s. 137). W takich uwarunkowaniach politycznych i społecznych przyszło funkcjonować Kościołowi prawosławnemu w pierwszym powojennym okresie Polski Ludowej.

Fr. Arkadiusz Barańczuk, Cerkiew prawosławna na terenie województwa białostockiego w latach 1944-1956, Warszawska Metropolia Prawosławna, Warszawa 2016, pp. 160.

\section{Bibliography / Bibliografia}

Apostołowie Słowian. Żywoty Konstantyna i Metodego, introduction T. Lehr-Spławiński, adenda L. Moszyński, Warszawa 1988.

Bendza M., Droga Kościoła prawosławnego w Polsce do autokefalii, Białystok 2006.

Bendza W., Regulacja kościelnych spraw majątkowych na przykładzie Kościoła prawosławnego w Polsce, Warszawa 2009. 
Białorusini i stosunki polsko-białoruskie na Białostocczyźnie 1944-1956, vol. 1: Sierpień 1944-grudzień 1956, part 1: Sierpień 1944-grudzień 1945, ed. S. Iwaniuk, Białystok 1996.

Caravia P., Constantinescu V., Stanescu F., The Imprisoned Church: Romania 1944-1989, Bucharest 1999.

Charkiewicz A., Równi Apostołom Oświeciciele Słowian, "Wiadomości PAKP” 2013, No 6.

Chomik P., Schizma bielska jako przykład problemów jurysdykcyjnych Kościoła prawosławnego na Białostocczyźnie w latach 1944-1946, [in:] P. Chomik, Cerkiew prawosławna w Polsce i krajach sasiednich. Od przeszłości do współczesnych problemów bezpieczeństwa, Białystok 2015.

Dominiczak H., Organy bezpieczeństwa PRL w walce z Kościołem katolickim 1944-1990. W świetle dokumentów MSW, Warszawa 2000.

Dudra S., Autokefalie Polskiego Autokefalicznego Kościoła Prawosławnego w polityce władz polskich i Patriarchatu Moskiewskiego, [in:] Polityka jako wyraz lub następstwo religijności, ed. R. Michalak, Sieniawa Żarska 2015.

Dudra S., Kościót prawosławny na terenie Polski południowo-wschodniej, "Limes. Studia i Materiały z dziejów Europy Środkowo-Wschodniej” 2010-2011, No 3-4, Rzeszów 2011.

Dudra S., Kościót prawosławny na ziemiach zachodnich i pótnocnych Polski po II wojnie światowej, Zielona Góra 2004.

Dudra S., Kościót prawosławny wobec przesiedleń ludności łemkowskiej do Ukraińskiej Socjalistycznej Republiki Radzieckiej w latach 1944-1946, [in:] Łemkowie, Bojkowie, Rusini-historia, współczesność, kultura materialna i duchowa, vol. 6, Słupsk 2016.

Dudra S., Kształtowanie się struktury administracyjnej prawosławnej diecezji wrocławsko-szczecińskiej po II wojnie światowej, "Studia Zachodnie" 2008, vol. 10.

Dudra S., Metropolita Dionizy (Waledyński) 1876-1960, Warszawa 2010.

Gerent P., Prawosławie na Dolnym Śląku w latach 1945-1989, Toruń 2007.

Gerent P., Wierni wyznania prawosławnego na Dolnym Ślasku w świetle powojennych migracji ludności, “Zeszyty Naukowe Studenckiego Koła Ukrainoznawczego”, z. 3, Wrocław 1996.

Kalkandjieva D., Balgarskata pravoslavna tsarkva i darzhavata 1944-1953, [in:] The Bulgarian Orthodox Church and the State, Sofia 1997.

Kołakowski P., NKWD i GRU na ziemiach polskich 1939-1945, Warszawa 2002.

Krawczyk M., Organy państwowo-partyjne odpowiedzialne za wytyczanie i realizowanie polityki wyznaniowej PRL, "Zeszyty Naukowe Uniwersytetu Przyrodniczo-Humanistycznego w Siedlcach" 2011, Seria Administracja i Zarządzanie, No 89.

Kułak J., Pacyfikacja wsi białoruskich w styczniu 1946 roku, "Biuletyn Instytutu Pamięci Narodowej" 2001, nr 8.

Kuprianowicz G., Akcja "Wisła” a Kościół prawosławny, [in:] Akcja "Wisła”, ed. J. Pisuliński, Warszawa 2003.

Kuprianowicz G., Prawosławie w Polsce od 1918 roku do współczesności, [in:] Prawosławie. Światło wiary i zdrój życia, ed. K. Leśniewski, Lublin 2009.

Łotocki A., Autokefalia. Zasady autokefalii, Warszawa 1932.

McGuckin J.A., The Orthodox Church. An Introduction to its History, Doctrine and Spiritual Culture, Oxford 2008.

Michalak R., Kościoły protestanckie i władze partyjno-państwowe w Polsce (1945-1956), Warszawa 2002.

Mironowicz A., Kościót prawosławny na ziemiach polskich w XIX i XX wieku, Białystok 2005.

Mironowicz A., Kościót prawosławny w państwie Piastów i Jagiellonów, Białystok 2003.

Mironowicz E., Antykomunistyczne podziemie na Białorusi i na Białostocczyźnie w latach 1944-1948. Pamięć, mitologia, historia, "Białoruskie Zeszyty Historyczne" 2010, nr 34.

Mironowicz E., Białorusini w Polsce 1944-1949, Warszawa 1993. 
Misiło E., Repatriacja czy deportacja. Przesiedlenie Ukrainców z Polski do USRR 1944-1946, vol. 2, Dokumenty, Warszawa 1999.

Osuchowski J., Prawo wyznaniowe Rzeczypospolitej Polskiej 1918-1939, Warszawa 1967.

Paiusan C., Ciuceanu R., The Romanian Orthodox Church under the Communist Regime, Vol. 1: 1945-1958, Bucharest 2001.

Papadakis A., Zarys dziejów Kościoła prawosławnego, [in:] Prawosławie. Światło ze wschodu, red. K. Leśniewski, Lublin 2009.

Papierzyńska-Turek M., Między tradycją a rzeczywistością. Państwo wobec prawosławia 1918-1939, Warszawa 1989.

Paprocki H., Prawosławie w Polsce, Olszanica 2008.

Pasterze wiernych Słowian: Święci Cyryl i Metody, oprac. A. Naumow, Kraków 1995.

Péter L., Church-State Relations and Civil Society in Hungary. A Historical Perspective, "Hungarian Studies" 1995, Vol. 10, No. 1.

Pisuliński J., Przesiedlenie ludności ukraińskiej z Polski do USRR w latach 1944-1947, Rzeszów 2009. Przybył E., Prawosławie, Kraków 2006.

Sawa (Hrycuniak), Ślady misyjnej działalności św. Metodego na ziemiach polskich, "Almanach Diecezjalny" 2005, vol. 1, Gorlice 2005.

Sosna G., Fonik D., Dzieje Cerkwi w Bielsku Podlaskim, Białystok 1995.

Sosna G., Fonik D., Szczyty. Dzieje wsi i parafii, Bielsk Podlaski-Ryboły-Białystok 2005.

Sychov A., The Liquidation and the Attempts of Reopening of the Congregations of the Estonian Eparchy during the Governance of Nikita Hruschtschov in 1954-1964, http://www.orthodoxa. org/GB/estonia/documentsEOC/closingGB.htm [access on: 10.09.2014].

Sychowicz K., Władze komunistyczne wobec Kościołów i związków wyznaniowych w województwie białostockim w latach 1944-1975, Białystok 2013.

Szwagrzyk K., Aparat bezpieczeństwa w latach 1944-1956, [in:] Aparat bezpieczeństwa w Polsce. Kadra kierownicza, t. 1: 1944-1956, red. K. Szwagrzyk, Warszawa 2005.

Świątkowski H., Stan prawny Polskiego Autokefalicznego Kościoła Prawosławnego, Warszawa 1939. Urban K., Kościót prawosławny w Polsce 1944-1956. Studia i materiały, Kraków 1998.

Urban K., Kościół prawosławny w Polsce 1945-1970, Kraków 1996.

Wojtkowiak S., Prawosławie wczoraj i dziś, Warszawa 1995.

Zyzykin M., Autokefalia i zasady jej zastosowania, Warszawa 1931.

Article submitted: 24.01.2017; article accepted: 12.03.2017 